\title{
Synthesis and Antimicrobial Activity of 4-aryl furo Pyridazines
}

\author{
Ashok Kumar Singh*, Narendra Kumar Srivastav \\ Department of Chemistry, Tri-Chandra Multiple Campus, Tribhuvan University, Nepal \\ Email asokksingh@yahoo.co.in
}

\begin{abstract}
Benzoyl hydrazides (1a-b) was condensed with furan-2-aldehyde (2) in the presence of sodium hydroxide and dry ethanol, furan-2-yl-benzoyl hydrazone (3a-b) was achieved. Intramolecular cyclization of compound $\mathbf{3 a - b}$ with PPE afforded 4-aryl furo pyridazines (4a-b)
\end{abstract}

Keywords: Furan aldehyde, furo pyridazines, hydrazides, hydrazones.

\section{Introduction}

Many pyridazine and related analogue were found to possess valuable properties such as antiangiogenic, anticancer, antineuroinflammatory, antimicrobial and anticonvulsant activities. Besides they exhibit antiviral activity against the replication of human immunodeficiency virus, inhibit human picornaviruses, protein kinase and acyl coenzyme A: cholesterol acyltransferase. ${ }^{1-9}$

In recent years, a substantial number of pyridazines have been reported to possess antimicrobial, antitubercular, antifungal, potent analgesic and anti-inflammatory .phosphodiesterase 4 (PDE4) inhibitors are effective anti-inflammatory drugs as potent and selective COX-2 inhibitors, antipyretic activities ,antidiabetic, antifeedant, insecticidal activities, antihypertensive and antiplatelet activities ${ }^{10}$.

Pyridazine derivatives are found in skeleton of some commercially available drugs. For instance, Apresoline contains hydralazine (4) as a pyridazine derivative that is used to treat hypertension for pregnant $^{11}$

Previously aryl-thieno[2,3-d]-pyridazine was synthesized by a different route to study the pentobarbital sleep in mice ${ }^{12}$. Further pyridazine analogues are synthesized and investigated as modulators of unwinding reaction mediated by west nile virus ${ }^{13}$. Based on these findings it was considered valuable to incorporate furan ring in pyridazine framework as in $\mathbf{4 a - b}$, which might enhance the biological activity. Herein we are reporting the conversion of 1-aroyl-hydrazones 3a-b to the corresponding pyridazines $\mathbf{4 a - b}$ using PPE in good yield.

\section{Experimental}

Melting points were determined in open capillary tube on the Buchi oil bath melting point apparatus. Infrared (IR) absorption spectra were recorded on FT-IR Shimadzu 8300 spectrometer using nujol mull. Proton nuclear magnetic resonance $\left({ }^{1} \mathrm{H}\right.$ NMR) spectra were routinely recorded either on a Hitachi R-600 $(60 \mathrm{MHz})$ spectrophotometer or on a Bruker $300 \mathrm{MHz}$ spectrophotometer in $\mathrm{CDCl}_{3}$ or $\mathrm{DMSO}^{-\mathrm{d}_{6}}$ and

\section{* Corresponding author}


absorptions are given in parts per million $(\delta)$ downfield using tetramethylsilane (TMS) as an internal standard.

\section{Furan-2-yl-2-methy21lbenzoyl hydrazone (3a)}

A mixture of acid hydrazide $1 \mathrm{a}(4.45 \mathrm{~g}, 0.036 \mathrm{~mol})$ and 2-furan aldehyde $(\mathbf{2}, 4.0 \mathrm{~g}, 0.035 \mathrm{~mol})^{33}$ and sodium hydroxide $(0.3 \mathrm{~g})$ was refluxed in dry ethanol $(30 \mathrm{ml})$ in round bottom flask for $5 \mathrm{~h}$. The reaction mixture was reduced to a small volume $(15 \mathrm{ml})$ by distilling off the ethanol. The pale yellow solid obtained was filtered washed with water to neutral ${ }^{\mathrm{pH}}$, dried and on recrystallization from ethanol gave yellow solid 3a $73 \%(5.55 \mathrm{~g})$ yield.

M.P. $170-172^{\circ} \mathrm{C}$

IR (Nujol): $1645(\mathrm{C}=\mathrm{N}), 1650$ (amide $\mathrm{C}=\mathrm{O}$ ), 3218-3320 $\mathrm{cm}^{-1}$ ( $\mathrm{NH}$ stretch)

${ }^{1} \mathbf{H}$ NMR (DMSO-d $\left.)_{6}\right): \delta 2.2\left(\mathrm{~s}, 3 \mathrm{H}, \mathrm{CH}_{3}\right), 6.8-7.8(\mathrm{~m}, 4 \mathrm{H}, \mathrm{Ar}-\mathrm{H}), 8.5(\mathrm{~s}, 1 \mathrm{H}, \mathrm{NH})$

Furan-2-yl-2-chlorobenzoyl hydrazone (3b):

Obtained from 2 (3.47 g, $0.031 \mathrm{~mol}), 2$-chlorobenzoyl hydrazide (1b $, 5 \mathrm{~g}, 0.029 \mathrm{~mol})$ and sodium hydroxide $(0.3 \mathrm{~g})$ in ethanol $(30 \mathrm{ml})$ as a pale yellow solid in $64 \%(4.85 \mathrm{~g})$ yield.

M.P. $180-192^{\circ} \mathrm{C}$

IR (Nujol): $1645(\mathrm{C}=\mathrm{N}), 1650$ (amide $\mathrm{C}=\mathrm{O}$ ), $3220-3360 \mathrm{~cm}^{-1}$ ( $\mathrm{NH}$ stretch)

${ }^{1} \mathbf{H}$ NMR (DMSO-d $\left.\mathbf{d}_{\mathbf{6}}\right)$ : 7.0-7.8 (m, 4H, Ar-H), 8.4 (s, 1H, NH)

General procedure for the synthesis of 4-Aryl furo pyridazines (4a-B)

A typical procedure is described for the preparation of:

\section{4-(2-Methylphenyl) furo[2,3-d]pyridazine (4a)}

Compound 3a $(3.0 \mathrm{~g}, 0.012 \mathrm{~mol})$ was added to a solution of $\mathrm{PPE}^{34}$. [prepared by refluxing phosphorous pentoxide $(50 \mathrm{~g})$, dry diethyl ether $(50 \mathrm{ml})$ and dry chloroform $(150 \mathrm{ml})$ for $26 \mathrm{~h}$.] and refluxed for $8 \mathrm{~h}$. The cooled reaction mixture was poured into ice $(250 \mathrm{~g})$, basified by adding $10 \%$ ammonium hydroxide (100 ml) and stirred for $15 \mathrm{~min}$. The organic layer separated was washed with 5\% sodium hydroxide solution $(3 \times 30 \mathrm{ml})$ and then with water $(3 \times 50 \mathrm{ml})$. After evaporating the solvent, the solid was recrystallized from benzene to give pale yellow crystalline solid in 64\% (1.80 g) yield.

M.P. $129-131^{\circ} \mathrm{C}$

IR (Nujol): $1630 \mathrm{~cm}^{-1}(\mathrm{C}=\mathrm{N})$

${ }^{1} \mathbf{H}$ NMR $\left(\mathbf{C D C l}_{3}\right): \delta 2.2\left(\mathrm{~s}, 3 \mathrm{H}, \mathrm{CH}_{3}\right), 7.0-7.5(\mathrm{~m}, 6 \mathrm{H}, \mathrm{Ar}-\mathrm{H}), 9.2\left(\mathrm{~s}, 1 \mathrm{H}, \mathrm{C}_{7}-\mathrm{H}\right)$

4-(2-Chlorophenyl) furo[2,3-d]pyridazine, (4b)

Obtained from $3 \mathbf{b}(3.44 \mathrm{~g}, 0.013 \mathrm{~mol})$, PPE $(30 \mathrm{ml})$ as pale yellow crystalline solid in $59 \% \quad(1.9 \mathrm{~g})$ yield.

M.P. $168-170^{\circ} \mathrm{C}$

IR (Nujol): $1630 \mathrm{~cm}^{-1}(\mathrm{C}=\mathrm{N})$

${ }^{1}$ HNMR (DMSO-d $\mathbf{6}_{\mathbf{6}}$ ): $\delta$ 7.0-7.5 (m, 6H, Ar-H), 9.3 (bs, 1H, $\mathrm{C}_{7}-\mathrm{H}$ ) 
<smiles>[R2]c1ccc(C(N)=O)c([R4])c1</smiles>

la-b

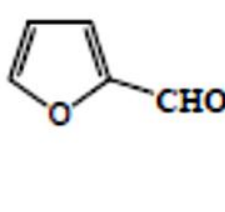

2

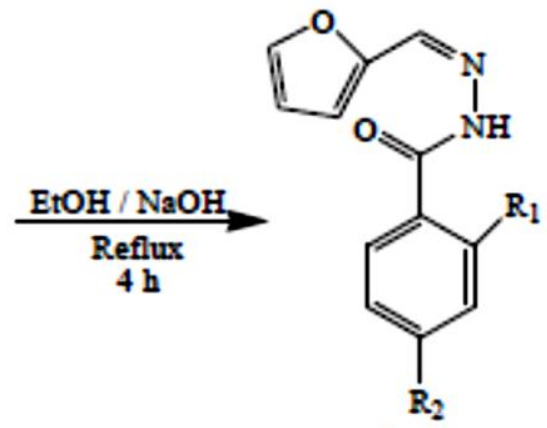

3a-b a: $\mathrm{R}_{1}=\mathrm{CH}_{3}, \mathrm{R}_{2}=\mathrm{H}$

b: $\mathrm{R}_{1}=\mathrm{Cl}, \mathrm{R}_{2}=\mathrm{H}$

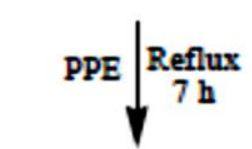

(N)

ta-b

\section{SCHEME-1}

\section{Results and Discussion}

The structure of synthesized compounds was elucidated by IR, NMR and microanalyses. The IR spectrum of 3a-b showed stretching absorption bands at 1645,1650 and $3218-3320 \mathrm{~cm}^{-1}$ assigned to $\mathrm{C}=\mathrm{N}$, $\mathrm{C}=\mathrm{O}$ and $\mathrm{N}-\mathrm{H}$ stretching respectively. In ${ }^{1} \mathrm{H}$ NMR spectrum, all protons were seen according to expected chemical shifts and integral values. The aromatic protons and amide proton of $\mathbf{3 a - b}$ were observed at $\delta$ 6.8-7.8 and 8.5 respectively.

Similarly the IR spectra of $\mathbf{4 a - b}$ showed absorptions at $1615-1630 \mathrm{~cm}^{-1}$ assigned to $\mathrm{C}=\mathrm{N}$ as a shoulder. The ${ }^{1} \mathrm{H}$ NMR spectra of $\mathbf{4 a - b}$ showed multiplet in the range $\delta$ 7.0-7.5 for six aromatic protons. Further, compounds $\mathbf{4 a - b}$ showed broad singlet at $\delta$ 9.1-9.3 due to $\mathrm{C}_{7}-\mathrm{H}$ and this down field absorption might be due to the presence of electronegative adjacent nitrogen atom.

Antimicrobial activity screening results are qualitative in nature (Table 1,2). The antibacterial screening results have shown that chloro substituted compounds $4 \mathrm{~b}$ exhibit, growth inhibitory activity 
more relevant than that of the reference compound. Even in case of antifungal activity chloro substituted compounds showed growth inhibitory activity more relevant than that of the reference drug.

\section{Antimicrobial activity}

The compound 4a-b was screened for antimicrobial activity using cup plate method. The activity was carried out against three pathogenic bacteria, B. Cereus, S. Aureus and E. Soli and two fungal culture, F. Solani, A. Favus. The standard drugs used were Chloromycetin and Griseofulvin. The compound was tested in dimethyl formaide. The zone of incubation was compared with standard drug after $43 \mathrm{hr}$ of incubation at 370 for antibacterial activity and $36 \mathrm{hr}$ at 370 antifungal activity. Antimicrobial activity screening results are summarized in Table 1 and 2.

Table 1: Antibacterial activity

\begin{tabular}{|ccccccc|}
\hline Compound. & $\begin{array}{c}\text { B. cereus } \\
\text { Area of } \\
\text { inhibition } \\
\mathrm{mm}^{2}\end{array}$ & $\begin{array}{c}\text { Relative } \\
\text { \% of } \\
\text { inhibition }\end{array}$ & $\begin{array}{c}\text { S. aureus } \\
\text { inhibition } \\
\mathrm{mm}^{2}\end{array}$ & $\begin{array}{c}\text { Relative } \\
\text { \% of } \\
\text { inhibition }\end{array}$ & $\begin{array}{c}\text { Area of } \\
\text { inhibition } \\
\mathrm{mm}^{2}\end{array}$ & $\begin{array}{c}\text { Relative\% } \\
\text { of } \\
\text { inhibition }\end{array}$ \\
\hline 4a & 287 & 80 & 420 & 91 & 188 & 88 \\
4b & 298 & 83 & 431 & 95 & 181 & 85 \\
\hline
\end{tabular}

Table-2: Antifungal activity

\begin{tabular}{|ccccc|}
\hline & \multicolumn{2}{c}{ F. Solani } & \multicolumn{2}{c|}{ A. Flavus } \\
Compound & $\begin{array}{c}\text { Area of } \\
\text { inhibition } \mathrm{mm}^{2}\end{array}$ & $\begin{array}{c}\text { Relative } \\
\text { \% of inhibition }\end{array}$ & $\begin{array}{c}\text { Area of inhibition } \\
\mathrm{mm}^{2}\end{array}$ & $\begin{array}{c}\text { Relative } \\
\% \text { of inhibition }\end{array}$ \\
\hline 4a & 133 & 28 & 172 & 50 \\
4b & 211 & 59 & 234 & 78 \\
\hline
\end{tabular}

\section{Conclusion}

The present work provides a useful method for the preparation of 4-aryl-furo[2,3-d]-pyridazines with moderate yields, as well as easily accessible starting materials. Further compounds with chloro group have shown more antibacterial, antifungal activities.

\section{Refrences}

1. Bongartz, J.P., Stokbroekx, R., Van der Aa, M., Luyckx, M., Willems, M., Ceusters, M., Meerpoel, L., Smets, G., Jansen, T., Wouters, W., Bowden, C., Valletta, L., Herb, M., Tominovich, R. and Tuman, R., Bioorg. Med. Chem. Lett. 12 (2002) 589.

2. Lattmann, E., Ayuko, W.O., Kinchinaton, D., Langley, C.A., Singh, H., Karimi, L. and Tisdale, M.J., J. Pharm. Pharmacol., 55 (2003) 1259. 
3. Mirzoeva, S., Sawkar, A., Zasadzki, M., Guo, L., Velentza, A.V., Dunlap, V., Bourguognon, J.J., Ramstrom, H., Haiech, J., Van Eldik, L.J. and Wastterson, D.M., J. Med. Chem., 45 (2002) 563.

4. el-Dean A. M. and Radwan S. M., Pharmazie, 53, (1998) 839.

5. Sivakumar, R., Anbalagan, N., Gunasekaran, V. and Leonard, J.T., Biol. Pharm. Bull., 26 (2003) 1407.

6. Galtier, C., Mavel, S., Snoeck, R., Andrei, G., Pannecouque, C., Witvrouw, M., Balzarini, J., De Clercq, E. and Gueiffier, A. Antivir. Chem. Chemother., 14 (2003) 177.

7. Hamdouchi, C., Sanchez-Maretinez, C., Gruber, J., Del prado, M., Lopez, J., Rubio, A. and Heinz, B.A., J. Med. Chem., 46 (2003) 4333.

8. Watterson, D.M., Velentza, A.V., Zasadzki, M., Craft, J.M., Haiech, J. and Van Eldik, L.J., J. Mol. Neurosci., 20 (2003) 411.

9. Toma, L., Giovannoni, M.P., Vergelli, C., Dal Piaz, V., Kwon, B.M., Kim, Y.K., Gelain, A. and Barlocco, D., Arch. Pharm., 335 (2002) 563.

10. M,Asif.,S,Anita.,S,A,Anees.,Med. Chem.Res.,DOI 10.1007/soo44-011-9835-6.,2011

11. Gracia, P.; Lasso, M.; Ruiz, E.; Vega-Malek, J. C.; Mena, F. T.; Lopez, J. C. Eur.

12. J. Obstet. Gynecol. Rep. Biol. 128 ( 2006) 157

13. Robert B. and Piser, M.J., Pat. Fr. Demande FR 2,463,145; through Chem. Abstr., 96 (1982)

14. Peter B., Melanie L., Annemarie H., Herbert S., Joonho C., Huan-Ming C., and Ramachandra 